\title{
Impact of Organizational Commitment on Civil Servants Performance: An Empirical Study of Alauddin Islamic State University of Indonesia
}

\author{
Syam'un, Mahfudnurnajamuddin, Syahrir Mallongi, Ramlawati, and Budiandriani
}

\section{ABSTRACT}

This study explores the contribution of organizational culture, competence, work motivation to organizational commitment, to organizational commitment and the performance of 220 civil servants who work in the administration section of Alauddin Islamic State University of Indonesia (Makassar). Data were analyzed using analysis of moment structures. The exploratory findings provide evidence that organizational culture and work motivation contribute fully and significantly in increasing organizational commitment, in contrast to competence the results are in opposite directions. In other causality, it was found that culture and organizational commitment significantly contributed to improving employee performance, while low work competence and motivation were not proven to contribute.

Keywords: Culture, competence, organizational commitment, performance, work motivation.

\author{
Submitted : February 25, 2021 \\ Published : March 18, 2021 \\ ISSN: 2507-1076 \\ DOI: $10.24018 /$ ejbmr.2021.6.2.778 \\ Syam'un * \\ Postgraduate School of Indonesian \\ Muslim University, Makassar, Indonesia. \\ (e-mail: syam’un@ gmail.com) \\ Mahfudnurnajamuddin \\ Indonesian Muslim University, Makassar, \\ Indonesia. \\ (e-mail: \\ mahfudnurnajamudin @ yahoo.co.id) \\ Syahrir Mallongi \\ Indonesian Muslim University, Makassar, \\ Indonesia. \\ (e-mail: syahrir.mallongi@umi.ac.id) \\ Ramlawati \\ Indonesian Muslim University, Makassar, \\ Indonesia. \\ (e-mail: ramlawati@umi.ac.id) \\ Budiandriani \\ Indonesian Muslim University, Makassar, \\ Indonesia \\ (e-mail: budiandriani@ ${ }^{\circledR}$ mi.ac.id) \\ *Corresponding Author
}

\section{INTRODUCTION}

The civil servants' apparatus (ASN) has a strategic role in governance and development. As a civil servant, the civil servants are required to provide fair and equitable services to the community based on loyalty and adherence to the Pancasila and 1945 Constitution. integrated approach. This integrated approach is expected that the state civil servants' apparatus will have more professionalism so that they can provide services and protection to the community. To continuously improve the quality of the government apparatus, among others, by optimizing its role as a driving force and development actor through increased performance. In this case, civil servants as state apparatus have a very important role in smoothing the running of the wheels of government and the implementation of national development.

Managing human resources in an organization is not easy because it involves various elements in an organization, namely employees, leaders, and the system itself. The combination of these three things is expected to be able to create a conducive organizational culture so that both members of the organization and leaders can carry out their work optimally.

The application of organizational culture has always been the concern of all elements in the organization, that organizational culture is the actualization of habits that have values and norms to be obeyed by every member of the organization. Values are the glue of all the values of sensitivity, freedom, courage, and openness to realize organizational goals [1].

This condition has an impact on the performance shown by the civil servants who work in the administration section of the Alauddin Islamic State University in Makassar. 2019 shows that out of 225 state civil servants, only $58 \%$ of state civil servants enter office on time and $42 \%$ of them are used to being late for office. The organizational culture fundamental theory explains that advanced and modern organizations are inseparable from the fundamental philosophy that adheres to five values, namely integrity, identity, responsibility, discipline, and orientation results [2]. This theory plays an important role in instilling an organizational culture of organizational members to increase individual job satisfaction and increase employee commitment in an organization [3]-[6]. 
Good organizational culture practices supported by employee competencies are important elements that can directly become obstacles in the implementation of their main duties and functions. Window theory explained if personal competence can be measured with education, skills, work experience, motivation, and mastery of technology [7]. Several previous studies analyzed the relationship between competency variables with organizational commitment and employee performance, the findings of this study prove that competence has a positive and significant effect on organizational commitment and employee performance [5], [8]-[15].

Another antecedent in increasing commitment and performance is work motivation which is a series of attitudes and values that influence individuals to achieve specific things according to individual goals [16]. Furthermore, these attitudes and values are invisible which provides, the strength to encourage individuals to behave in achieving their goals. The drive consists of two components, namely the direction of work behavior that achieves goals and the strength of the behavior (how strong the individual effort is at work).

Motivation includes unique feelings, thoughts and past experiences that are part of the company's internal and external relationships. Besides, motivation can also be interpreted as encouraging individuals to take action because they want to do it. If individuals are motivated, they will make positive thoughts to do something because it can satisfy their desires. Basically, motivation can help motivate employees to work hard so that they can achieve their goals. This will improve its performance to achieve organizational goals.

The results of observations show that some of the employees are still not satisfied with the motivation they receive, especially those related to their daily economic needs. Symptoms of dissatisfaction felt by some employees can affect employee commitment to the organization. This can be seen from the achievement of work realization that is not following the specified targets. So far, employee performance appraisals at Alauddin Islamic State University have been based on Indonesian Government Regulation Number 46 of 2011 concerning civil servants' performance assessment which includes service orientation, integrity, commitment, discipline, cooperation, and leadership. The facts show that job satisfaction and performance of administrative staff still shows the percentage has not reached the expected target.

TABLE I: Percentage of Job SATISFACtion AND Civil SERVAnts' PERFORMANCE

\begin{tabular}{ccccc}
\hline \multirow{2}{*}{ Periods } & \multicolumn{3}{c}{ PERFORMANCE } \\
\cline { 2 - 5 } & Percentage of job satisfaction & \multicolumn{2}{c}{$\begin{array}{c}\text { Percentage of civil } \\
\text { servants' performance }\end{array}$} \\
\cline { 2 - 5 } 2015 & Actual & Target & Actual & Target \\
2016 & 73,16 & $90-100$ & 85,52 & $90-100$ \\
2017 & 76,42 & $90-100$ & 84,74 & $90-100$ \\
2018 & 82,71 & $90-100$ & 82,91 & $90-100$ \\
2019 & 82,46 & $90-100$ & 81,72 & $90-100$ \\
\hline \hline
\end{tabular}

The job satisfaction shown by civil servants, that the realization is still below the specified standard or target. Low employee job satisfaction indicates low employee commitment to their duties and functions. The view of determining job satisfaction as a determinant of organizational commitment is based on the assumption that job satisfaction is an individual's perception of the organization.

This perception reflects the perspective (insight) of individuals on policies and conditions that apply within the organization. Nevertheless, some have argued that job satisfaction is actually an attitude(attitude)parallel position with organizational commitment [17]. Various studies have proven that there is a close relationship between organizational commitment and employee performance [12], [18]-[20].

\section{LITERATURE REVIEW AND HYPOTHESIS}

\section{A. Organizational Culture}

Advanced and modern organizations have a fundamental philosophy that binds every member of the organization to have cultural adhesive values in advancing the organization or company. The adhesive values of organizational culture in question are integrity, identity, responsibility, discipline and results orientation in managing the organization [2]. Organizational culture is a set of values that are learned, believed, have a standard of knowledge, morals, law and behavior conveyed by individuals, organizations or communities to act according to the basic habits of seeing themselves [21].

Organizational culture plays an important role in the creation of job satisfaction and performance of individuals and organizations. The reality is that individuals who are sensitive to progress strive to improve their work abilities, by developing freedom of work creation for work optimization, individuals have the courage to develop job opportunities to achieve work performance and continue to carry out more professional work transparency [1], [22]. Employees who have organizational culture, high competence and motivation in carrying out each job will be happy to work so that without realizing it they have shown their commitment to the organization, which is shown by acceptance of the values and goals of the organization, their readiness and willingness to do their best. really on behalf of the organization and remain in the organization.

The relationship between culture and organizational commitment shows a linear direction [4], [23]. These findings are inconsistent with other findings, that organizational culture has a negative and insignificant effect on organizational commitment [6]. On other causality, there is evidence that organizational culture has a positive and significant effect on employee performance [6]. Measurements used in organizational culture, namely innovation, paying attention to things in detail, orientation to results, orientation to employees, and orientation to the team.

\section{$\mathrm{H}_{1 \mathrm{a}}$ : A good organizational culture is proven to} increase organizational commitment.

$\mathrm{H}_{1 b} \quad$ : The better the organizational culture will have a real impact on improving civil servants' performance.

\section{B. Competence}

Competence is the ability that must be possessed by an individual or every worker to be able to carry out a job (position) successfully (effectively, efficiently, productively and with quality) in accordance with the vision and mission 
of the organization. The definition of competency describes the abilities possessed by employees which contain a set of knowledge, skills, expertise, and attitudes obtained from learning activities. Individual competence is something inherent in itself that can be used to predict the level of performance. Competence is a characteristic that underlies a person and is related to the effectiveness of individual performance in their work [24]. Competence is work ability which has 3 (three) criteria consisting of intellectual ability regarding the job or position as the main task; ability to plan, carry out work or position and assess the results using tools through collaborative activities; and the ability to measure and assess progress in work with an orientation towards efficiency, effectiveness, and productivity [25], [26].

Empirical facts show that competence has a positive and significant effect on organizational commitment [5]. Similar facts are found in the causality between competence and employee performance [12, [14]. The dimensions used in analyzing the latent variables of competence are intellectual, emotional, social, and spiritual competence.

$\mathrm{H}_{2 \mathrm{a}} \quad$ : The higher the competency of employees, the higher the organizational commitment

$\mathrm{H}_{2 b}$ : High competence has a real impact on improving the civil servants' performance.

\section{Work Motivation}

Motivation predicts effort, joint efforts with individual traits and organizational aids predict performance. A person who is highly motivated is a person who makes substantial efforts to support his work goals and the organization in which he works. Whereas someone who is not motivated gives only minimum effort in terms of work. In other words, motivation is an important determinant of individual performance. Work motivation is a series of attitudes and values that influence individuals to achieve specific things according to individual goals [16].

Motivation is a concept used to describe the impulses that arise in or within an individual that drives and directs behavior. Motivation is the desire that exists in an individual who stimulates to take action [6], [27], [28]. Furthermore, he revealed several important factors that influence motivation, namely: personal needs, goals, and perceptions of the person or group concerned, and in what ways the needs and goals of work motivation have a positive and significant effect on organizational commitment [5]. The inconsistency of the findings is proven in other studies, that motivation has a positive and insignificant effect on organizational commitment [6].

Another causality proves that work motivation has a positive and significant effect on employee performance [14], [29], [30]. Indicators in measuring employee work motivation variables, namely economic needs, security, respect, social interactions, and self-actualization needs.
$\mathrm{H}_{3 \mathrm{a}}$ : High work motivation makes a real contribution to increasing organizational commitment.
$\mathrm{H}_{3 \mathrm{~b}}$ : The higher the work motivation, the more increasing of civil servants' performance.

\section{Organizational Commitment}

The measure of the strength of an employee's identification with the goals and values of the organization and being involved in it is a representation of, organizational commitment which serves as a better indicator for employees who wish to remain at their job or wish to move [31]. Organizational commitment is a state or degree to which an employee side with a particular organization with its goals and maintains membership in that organization [32].

Increasing organizational commitment is very important for the motivation and quality of employees who work in the public sector because public services require a good level of commitment, if the commitment of an employee is good, the public service is also good and vice versa, while the public service has been influenced by culture. existing [33], [34].

Employees want to contribute to achieving organizational goals were to achieve these organizational goals has been influenced by the nature of different commitments, so that these demands become even more urgent when fiscal flexibility begins to decline as it is today, while managers in government circles have the ability to very limited to providing extrinsic rewards such as promotions and raises (position) [35]-[37]. The measurement used in analyzing the latent variables of organizational commitment, namely proud to be part of the organization, care about the fate of the organization, loyalty to the organization, a strong belief in organizational values, and feeling good about the organization.

$\mathrm{H}_{4}$ : The higher organizational commitment in the direction of creating civil servants' performance.

\section{E. Civil Servants Performance}

Performance is a set of results that are achieved and refers to the action of achievement and implementation of the requested work and performance is a function of motivation and ability [38]. Conditions that must be known and informed to certain parties to determine the level of achievement of an organization's results related to the vision and mission of an organization and to know the positive and negative impacts of predetermined operational policies are a representation of performance.

Performance is used by management to periodically assess the operational effectiveness of an organization, the effectiveness of employees based on their main duties and functions and based on predetermined standards. Performance in both individuals and organizations can be used as a means of controlling the success of the organization [39]. The indicators used to measure employee performance are the level of work quality, quantity standards, efficiency, and professionalism.

$\mathrm{H}_{5 \mathrm{a}}$ : Organizational commitment plays a real role as a mediator of organizational culture on civil servants' performance.

$\mathrm{H}_{5 \mathrm{~b}}$ : Organizational commitment plays a real role as a mediator of competence on civil servants' performance.

$\mathrm{H}_{5 \mathrm{c}}$ : Organizational commitment has a real function in supporting the relevance of work motivation to civil servants' performance. 


\section{RESEARCH METHODS}

The research approach is explanatory research, using 211 civil servants in the administration section of Alauddin State Islamic University Makassar as the unit of analysis. Data were analyzed using Structural Equation Modeling through the analysis of a moment structures

\section{RESUlts}

TABLE II: VALIDITY AND RELIABILITY

\begin{tabular}{|c|c|c|c|}
\hline Measure & Items & $\begin{array}{c}\text { Pearson } \\
\text { correlation }<0.05\end{array}$ & $\begin{array}{c}\text { Cronbach's } \\
\text { alpha }\end{array}$ \\
\hline \multirow{5}{*}{ Cul. } & Cul_1 & 0.84 & \multirow{5}{*}{0.85} \\
\hline & Cul_2 & 0.91 & \\
\hline & Cul_3 & 0.86 & \\
\hline & Cul_4 & 0.84 & \\
\hline & Cul_5 & 0.86 & \\
\hline \multirow{4}{*}{ Comp. } & Comp_1 & 0.82 & \multirow{4}{*}{0.80} \\
\hline & Comp_2 & 0.83 & \\
\hline & Comp_3 & 0.81 & \\
\hline & Comp_4 & 0.84 & \\
\hline \multirow[t]{5}{*}{ Mot. } & Mot_1 & 0.87 & \multirow{5}{*}{0.84} \\
\hline & Mot_2 & 0.84 & \\
\hline & Mot_3 & 0.86 & \\
\hline & Mot_4 & 0.80 & \\
\hline & Mot_5 & 0.90 & \\
\hline \multirow[t]{5}{*}{ Comtt. } & Comtt_1 & 0.82 & \multirow{5}{*}{0.80} \\
\hline & Comtt_2 & 0.88 & \\
\hline & Comtt_3 & 0.82 & \\
\hline & Comtt_4 & 0.86 & \\
\hline & Comtt_5 & 0.84 & \\
\hline \multirow[t]{4}{*}{ Perf. } & Perf__-1 & 0.80 & \multirow{4}{*}{0.83} \\
\hline & Perf_2 & 0.79 & \\
\hline & Perf_3 & 0.87 & \\
\hline & Perf_4 & 0.61 & \\
\hline
\end{tabular}

All latent variables analyzed were declared valid $r>0.30$ and p-value $<0.05$ and had a reliability level of $>0.60$.

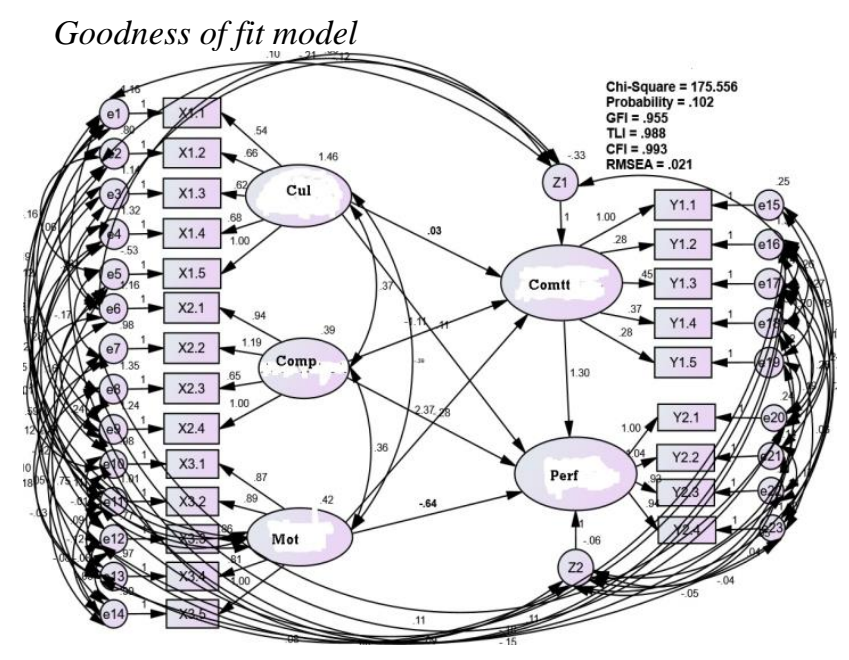

Fig. 1. Goodness of Fit.

Fig. 1. shows good results because it has met the required goodness of fit, for which the results can be shown as follows:

\begin{tabular}{ccc}
\multicolumn{3}{c}{ TABLE III: OVERALL GOODNESS OF FIT MODEL TEST } \\
\hline \hline GOF & Result & Cut-off \\
\hline Chi-Square & 226,498 & Expected Small \\
Probability & 0,102 & $\geq 0,05$ \\
RMSEA & 0,021 & $\leq 0.08$ \\
GFI & 0,955 & $\geq 0.90$ \\
AGFI & 0,919 & $\geq 0.90$ \\
TLI & 0,988 & $\geq 0.95$ \\
CFI & 0,993 & $\geq 0,95$ \\
CMIN/DF & 1,0147 & $\leq 2.00$ \\
\hline \hline
\end{tabular}

Table III can be explained that the significance level of 0.102 indicates that the null hypothesis which states there is no difference between the sample covariance matrix and the estimated population covariance matrix is acceptable. With the acceptance of the null hypothesis, it means that there is no difference between the sample covariance matrix and the estimated population covariance matrix, so the model is feasible to use. Other indices (CMIN / DF, GFI, AGFI, TLI, CFI, and RMSEA) also show the level of acceptance of the model.

\section{A. Organizational Culture on Organizational Commitment}

The results of this study support the proposed hypothesis, it can be proven by a positive regression coefficient of 0.056 and a significance value of 0.031 or less than 0.05 . The organizational culture that is owned has contributed to increasing employee commitment to the organization. This situation can mean that most of the employees have been driven to work innovatively, and have self-confidence in doing every job; employees have tried to work with a high level of accuracy, and strive to work with attention to things in detail; generally employees always pay attention to the work result, and always prioritize adherence to processes and procedures; the organization always provides satisfaction guarantees and social security for employees who display high performance; and the importance of cooperation and the importance of the ability to work as a team.

This finding is relevant to previous evidence that organizational culture has a positive and significant effect on organizational commitment [4], [5], [12]. Rejecting previous findings that organizational culture has a negative and insignificant effect on organizational commitment [6].

\section{B. Organizational Culture on Civil Servants' Performance}

The results show that the proposed hypothesis is proven to be accepted. This is evidenced by the positive regression coefficient of $0.178 \mathrm{p}$-values, $0.009<0.05$. The application of organizational culture by employees is in the high or good category, with an average of 4.13. The five indicators of organizational culture have been well implemented, namely employees have implemented innovation and the courage to take risks; employees pay attention to detail, employees are results-oriented; to colleagues and the work team. The results of this study support previous findings that organizational culture has a positive and significant effect on the performance of employees or organizational members [6], [14].

\section{Competence on Organizational Commitment}

The findings of this study reject the proposed hypothesis, as evidenced by the negative regression coefficient of 0.935 and a significance value of 0.081 or greater than 0.05 . This situation indicates that the skills of employees in their respective fields of work and low professional attitudes at work; Self-control among employees has not been carried out properly, the ability to establish working relationships is low, and the ability to be flexible and the level of self-disclosure of employees is low. This study rejects the findings of previous researchers that employee competence has a positive and significant effect on organizational commitment [5], [8], [19]. 


\section{Competence on Civil Servants' Performance}

Competency improvement is a strategy directed at improving the performance of employees or members of the organization in carrying out their work efficiently, effectively, and responsibly. Employees or members of the organization will improve their performance if they are highly competent, have high work interest, and believe that their goals will be achieved. The proposed hypothesis is rejected because the regression coefficient is negative $=$ 0.230 and p-value $=0.059>0.05$. Employee competence possessed by employees cannot improve performance, as evidenced by the low quality and quantity of work, efficiency of the ability to work professionally. The low competence of employees related to intellectual competence and emotional competence is because there are still many employees whose educational levels are still low. This study is relevant to the findings of previous researchers, that competence has a negative and insignificant effect on employee performance [9], [11]. Refuting the findings of other researchers that competence has a positive and significant effect on employee performance [8], [12]-[14], [19].

\section{E. Work Motivation on Organizational Commitment}

The findings of the study prove the hypothesis that employees are well motivated to carry out their duties and obligations as employees. This is evidenced by the statements of some of the respondents, who said that their economic needs, security needs, appreciation needs, social interaction needs, and self-actualization needs have been met.

Around $92.40 \%$ of employees said they were satisfied or very satisfied with meeting economic needs; as much as $90.60 \%$ of the employees who said they were satisfied or very satisfied with the fulfillment of the need for security; as many as $46.90 \%$ of employees who said they were satisfied or very satisfied with the need for awards, as many as $82.70 \%$ of employees who said they were satisfied or very satisfied with the need for social interaction, and as many as $40.20 \%$ of employees who said they were satisfied or very satisfied with the fulfillment of the need for self-actualization. The results of this study are consistent with the results of previous studies that work motivation has a positive and significant effect on organizational commitment [4], [6], [8], [29].

\section{F. Work Motivation on Civil Servants' Performance}

A positive mental attitude of employees towards work situations will strengthen their work motivation to achieve maximum performance. Three elements are the key to motivation, namely effort, organizational goals, and needs. So, motivation in this case is a response to an action and arises from within humans because of the encouragement of an element of a goal. The proposed hypothesis is rejected because the regression coefficient is negative $=-0.553$ and $p$ value $=0.071>0.05$. There are still some employees who at work are not oriented towards the need for appreciation and self-actualization needs.

The findings of this study are relevant to previous studies that work motivation has a negative and insignificant effect on employee performance [9]. Rejecting the findings of other researchers, that work motivation has a positive and significant effect on employee performance [5], [8], [12], [14].

\section{G. Organizational Commitment on Civil Servants' Performance}

The high Employees with organizational commitment have different attitudes than those with low commitment. High organizational commitment results in work performance, low levels of absences, and low levels of turnover employee or employee. High commitment makes individuals care about the fate of the organization and strives to make the organization a better direction. The hypothesis proposed is accepted, as evidenced by the regression coefficient value is positive $=1.289$ with $\mathrm{p}$-value $=0.000<0.05$. Acceptance of this hypothesis is due to employees' pride in the organization, concern for the organization, loyalty to the organization, strong belief in organizational values, and feeling happy about the organization where they work.

This condition has an impact on improving performance, which is shown by prioritizing quality work results, completing work that is done well and the ability to complete priority work and the implementation of work by the field of expertise. The results of this study are in line with previous findings, that organizational commitment has a positive and significant effect on employee performance [8], [11], [18], [19], [29]. The inconsistency of the findings is shown in other studies, that organizational commitment has a negative and insignificant effect on employee performance [6].

\section{H. The role of Organizational Commitment as Mediation. Contribution of Organizational Culture to Civil Servants' Performance}

Organizational culture indirectly has a positive and significant effect on employee performance through organizational commitment, as evidenced by the value of the regression coefficient of 0.073 and a significance value of 0.011. This means that if organizational culture and organizational commitment are improved, employee performance will increase. The results of this study indicate that both directly and indirectly organizational culture has a positive and significant effect on employee performance. This means that the better the organizational culture, the better the employee performance will be, whether mediated by organizational commitment or not mediated by organizational commitment. The study confirms the findings of previous researchers that organizational culture has a positive and significant effect on employee performance through organizational commitment [6].

\section{The Role of Organizational Commitment as Mediation. Contribution of Competence to Civil Servants' Performance}

Competence indirectly has a negative and insignificant effect on employee performance through organizational commitment, which is proven by the indirect effect value = 1.205 and p-value 0.083>0.05. This means that although competence and organizational commitment are improved, they are not yet fully able to improve employee performance. This condition is caused because employees have low competence, especially intellectual competence and emotional competence.

These results confirm previous findings that competence has a negative and insignificant effect on employee performance through organizational commitment [11]. In contrast to other studies, competence has a positive and 
significant effect on employee performance through organizational commitment [8], [19].

\section{J. The role of Organizational Commitment as Mediation. Contribution of Work Motivation to Employee Performance}

Work motivation indirectly has a positive and significant effect on employee performance through organizational commitment, as evidenced by the indirect effect value $=$ 2.658 and $p$-value $=0.039<0.05$. This means that to improve employee performance, an increase in intellectual, emotional, social, and spiritual competence is needed through employee pride to be part of the organization, concern for the organization, loyalty to the organization, a strong sense of trust in organizational values, and feel good about the organization. The results of this research confirm previous findings that work motivation has a positive and significant effect on employee performance through organizational commitment [6], [8], [29].

\section{CONCLUSION}

The better the application of organizational culture, the greater the commitment of employees to the organization. Similar results are also shown in high work motivation to be an antecedent of commitment. In other causality, it is found that employees' low competency is so that they cannot increase their commitment to the organization. The reality shows that the implementation of a good organizational culture can improve employee performance. This condition is also found in the high employee commitment which has a significant correlation in improving employee performance.

Employee performance improvement in this study was not found in the contribution of employee competence and work motivation, this is due to low employee competence and work motivation shown by employees at a low level. The role of organizational commitment as mediation is only found in the contribution of organizational culture and work motivation, but the role of this commitment is not proven in explaining the contribution of competence to employee performance. It takes serious efforts from the campus bureaucracy to improve the intellectual and emotional competence of employees, one of which can be done by increasing the educational qualifications of employees. To increase work motivation, good cooperation between employees and the campus bureaucracy is needed by increasing the fulfillment of the need for appreciation and the need for employee selfactualization.

\section{REFERENCES}

[1] Handy, H. (2007). Work Responsibilities and Commitments. Publisher Tarsito, Bandung.

[2] Algerrow, MG. Adam. (2008). Human Resource Management, West Publishing Company, New York.

[3] Sunadji, E. A. T., \& Surachman, A. (2013). The Role of Organizational Culture, Leadership, Communication, and Job Satisfaction on Employee Performance (Study on Public Enterprise of Water Resource Management of Ministry State-Owned Enterprise). Journal of Business and Behavioral Sciences, 3(2), 34-42.

[4] Ghina, A. (2012). The influence of corporate culture on organizational commitment: A case study of civil government organizations in Indonesia. International Journal of Basic \& Applied Sciences, 1(2), 156-170.
[5] Siti Zaleha, Mohd. Aizat Abdull Manaf, \& Farhana Quoquab. (2016) Competence, Motivation and Organizational Commitment in the Islamic Banking Context: The Role of Organizational Culture as a Mediator, American Journal of Economics, Vol. 5, No. 5C.171-176.

[6] Winardi, Jasman, \& Said Musnadi. (2016). The Influence of Organizational Culture and Motivation on Employee Performance with Organizational Commitment as an Intervening Variable (Study at the Aceh Provincial Irrigation Service). Journal of Management Science, Graduate School of Syiah Kuala University, Volume 1 (1), May 2016: $1-24$.

[7] Bartlett, CA, \& Ghoshal, S. (1997). The myth of the generic manager: new personal competencies for new management roles. California management review, 40 (1), 92-116.

[8] Thorlaxone, AJ, \& Murray, RP (1996). An empirical study of empowerment in the workplace. Group \& Organization Management, 21 (1), 67-83.

[9] Harrison, Rosemary. (2011) Analysis of Culture Organization, Competence Motivation toward, Commitment to Increasing the Performance of Employee in Florida Government. Administration Science Science Quarterly June. 91-96.

[10] Andriani, R. (2014). The Influence of Organizational Culture and Competence on Employee Job Satisfaction at State Savings Bank in Bandung. Journal of Ecodemica: Journal of Economics, Management, and Business, 2 (2), 247-257.

[11] Akram Zaki. (2014). The Influence of Motivation, Work Facilities, and Competence on Organizational Commitment and Employee Performance at the Transportation Agency in South Sumatra Province. Journal of Business and Economics (JBE), Vol. 18, No. 1. 170-187.

[12] Kartini. (2015). The Influence of Competence, Organizational Commitment, and Organizational Culture on Job Satisfaction and Employee Performance at the Regional Secretariat of East Kutai Regency. Paradigm Journal, Vol. 4. No.1

[13] Gae-Liang Wang, Yu-Je Lee, \& Chuan-Chih Ho. (2017). The Effects of Job Satisfaction, and Competence on Employee Performance: As Exemplified with Employees of Listed Property Insurance Companies in Taiwan. Research in Business and Management, Volume 1 (2), August 2012: 41-53.

[14] Deswarta, D. (2017). The Influence of Competence and Motivation on Job Satisfaction and Lecturer Performance at the Faculty of Tarbiyah and Teacher Training, UIN Sultan Syarif Kasim Riau. Currency, 3 (1), 19-39.

[15] Yusuf, A. (2018). The Influence of Organizational Culture and Competence on Work Motivation at PT. Harmonious Mitra Sejahtera. Value: Journal of Management and Business, 3 (1).

[16] Nadler, David. (2017). Managing Organizations, Reading and Cases. Boston, Toronto Little, Brown and Company.

[17] Barney, J. B., \& Griffin, R. W. (1992). The management of organizations: Strategy, structure, behavior. Houghton Mifflin College Div.

[18] Malik, M. E., Nawab, S., Naeem, B., \& Danish, R. Q. (2010). Job satisfaction and organizational commitment of university teachers in the public sector of Pakistan. International journal of business and management, 5(6), 17.

[19] Sarminah, S. (2015). The Effects of Competence and Organization Commitment on Job Satisfaction and Job Performance Relationship: A Case of Managers in Malaysia's Manufacturing Companies. European Journal of Social Sciences, Volume 22, Number 3 (2015): 421-429.

[20] Dizgah, M. R., Chegini, M. G., \& Bisokhan, R. (2012). Relationship between job satisfaction and employee job performance in Guilan public sector. Journal of Basic and Applied Scientific Research, 2(2), 1735-1741.

[21] Robbins, S. P., \& Judge, T. A. (2013). Organizational behavior (Vol. 4). New Jersey: Pearson Education.

[22] Ndraha, Taliziduhu. (2014). Organizational culture. Rineka Cipta Publisher, Jakarta.

[23] Melina Taurisa, C., \& Intan, R. (2012). Analysis of the influence of organizational culture and job satisfaction on organizational commitment in improving employee performance (Study at PT. Sido Appears Kaligawe Semarang). Journal of Business and Economics, 19(2).

[24] Mitrani, A. (1995). Competency-Based Human Resource Management (translation). PT. Intermasa. Jakarta.

[25] Nawawi, Hadari, (2012). Human Resource Management for Competitive Business. Gadjah Mada University Press. Yogyakarta.

[26] Syam, EB, Pascawati, PNS, \& Sjahruddin, H. (2020). Contribution of Islamic Leadership Style Dimensions to Teacher Performance. Journal of Economics and Business Dharma Andalas, 22 (2), 210-220.

[27] Gibson, L. James, Ivancevich, M. John, \& Donnely, H. James, (2017). The organization, Process Structure Behavior, Volume 1, Fifth Edition, Translation, Jakarta: Erlangga. 
[28] Kanto, M., \& Sjahruddin, H. (2020). How Psychological Capital Mediates the Relationship Between Thriving at Work and Happiness At Work? A Cross-Sectional Research for Tourism Sector of Indonesia. PalArch's Journal of Archaeology of Egypt/Egyptology, 17(6), 1798-1812.

[29] Fatima Bushra, Ahmad Usman, \& Asvir Naveed. (2014). Effect of Transformational Leadership and Motivation on Organizational Commitment and Performance in Banking Sektor of Pakistan. Internaltonal Journal of Business and Social Science, Vol. 1, (16). 142 150.

[30] Sjahruddin, H., \& Anisyar, AN (2021). Benefits, Incentives and Discipline as Determinants of Employee Performance. (JMK) Journal of Management and Entrepreneurship, 6 (1), 73-85.

[31] McKenna, Eugene. (2014). The Essence: Human Resource Management. Publisher Elex Media Komputindo, Jakarta.

[32] Jewell, LL \& Marc Siegall, (2015). Modern Industrial or Organizational Psychology. Translation of Hadyana Pudjatmaka and Meitasari, Arcan Publisher, Jakarta.

[33] Sjahruddin, H., \& Sudiro, A. A. (2013). Organizational justice, organizational commitment and trust in manager as predictor of organizational citizenship behavior. Interdiciplinary J. of contemporary Res. Bus. (IJCRB), 4(12), 133-141.

[34] Suliman, Abubakar MT, (2014). Is it Really a Mediating Construct? Journal of Management Development, Vol. 14, No.7.

[35] Meyer, J.P., \& Allen, N.J. (1991). A three component conceptualization of organizational commitment. Human Resource Management Review 1, 61-89.

[36] Nyhan. R.C., (2013). Changing the Paradigm: Trust and its Role in Public Sector Organisations'. American Review of Public Administration. 30(1): 87-109.

[37] Toban, C., \& Sjahruddin, H. (2016). The antecedent and consequence of Organizational Commitment and Job Satisfaction. Journal of Business and Management Sciences, 4(2), 26-33.

[38] Gibson, L. James, Ivancevich, M. John, \& Donnely, H. James, (2017). Organization, Process Structure Behavior, Volume 1, Fifth Edition, Translation, Jakarta: Erlangga.

[39] Gomes, Faustino Cardoso., (2013). Human Resource Management, Andi Offset, Yogyakarta. 